\title{
Analisis Penerapan Metode Scrum Pada Sistem Informasi Manajemen Proyek Dalam Industri \& Organisasi Digital
}

\author{
Hisyam Rahmawan Suharno ${ }^{1}$, Nyoman Gunantara ${ }^{2}$, Made Sudarma ${ }^{3}$ \\ [Submission: 09-09-2020, Accepted: 17-12-2020]
}

\begin{abstract}
The rapid evolution of information technology in this era requires appropriate adjustments in utilizing information technology. All fields of life require some forms of information technology, particularly digital organizations and digital industries that are heavily reliant on information system. In order to create an information system, a software development method is needed. There are various types of software development methods, one of which is often used is the SDCL Waterfall method. SDCL Waterfall in principle follows organized and systematic stages. The Waterfall method emphasizes clearly the requirements for a software that will be developed. Therefore, some problems when a software will be developed like the initial requirements are not so clear and the possibility for changes during development. In line with the evolution of technology, the software development method has also evolved. There is a new method known as the scrum method. The scrum method is allegedly faster and more efficient. This translates to a more flexible implementation as this method prioritizes fast iteration or delivery based on functionality of the software that will be developed. However, not all software development is compatible with the scrum method, therefore this research will conduct a literature study to observe the effectiveness of applying the scrum method to digital industries \& organizations, and to find out whether the scrum method is truly reliable as a software development work scheme in an industry or digital organization.
\end{abstract}

Keywords: Scrum Method, Agile Methodology, Project Management, SDLC, Digital Industry, Organization.

Intisari - Dengan perkembangan teknologi informasi yang sangat pesat pada zaman ini membutuhkan penyesuaian yang tepat dalam pemanfaatan teknologi informasi tersebut. Pemanfaatan teknologi informasi sudah mencakup kesegala bidang kehidupan termasuk organisasi maupun industri digital. Didalam sebuah organisasi atau industri digital pasti akan memerlukan suatu aplikasi maupun sistem informasi. Didalam membuat sebuah sistem informasi maka diperlukanlah suatu metode pengembangan perangkat lunak. Metode pengembangan perangkat lunak berbagai macam jenisnya, salah satunya yang sering dipakai adalah metode $S D C L$ Waterfall. SDCL Waterfall pada prinsipnya mengikuti tahapan - tahapan yang terorganisir dan sistematis. Metode Waterfall sangat menekankan kepada requirement yang jelas pada suatu perangkat lunak yang akan di kembangkan.

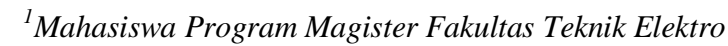
Universitas Udayana, Jl. Beringin No. 109 Dalung, Badung 80361 Bali - Indonesia (tlp: 082257359698; e-mail:

hisyam.rahmawan@student.unud.ac.id)

${ }^{2,3}$ Dosen Program Magister Fakultas Teknik Elektro Universitas Udayana, Jl. P.B Sudirman, Dauh Puri, Denpasar Barat 80361 Bali - Indonesia (telp:0361-223797; fax: - ; e-mail: gunantara@unud.ac.id², msudarma@unud.ac.id ${ }^{3}$ )
Maka daripada itu sering terjadinya masalah ketika suatu perangkat lunak yang akan dikembangkan tetapi kebutuhan awal belum begitu jelas dan kemungkinan untuk perubahan pada saat development besar kemungkinannya. Seiiring berkembangnya teknologi, maka metode pengembangan perangkat lunakpun mengalami perkembangan, maka muncullah sebuah metode baru yaitu metode scrum. Metode scrum muncul karena metode ini lebih cepat dan efisien yang bisa lebih flexible dalam pengimplementasiannya karena metode ini mengutamakan iterasi atau delivery yang cepat berdasarkan fungsionalitas dari perangkat lunak yang akan dikembangkan. Metode scrum dalam pengimplementasiannya tidak hanya sebagai model untuk pengembangan perangkat lunak akan tetapi lebih kepada manajemen pengembangan perangkat lunak yang bisa mengatur suatu pengembangan perangkat lunak agar lebih efisien. Akan tetapi tidak semua proyek pengembangan perangkat lunak cocok dengan metode scrum. Maka dari pada itu penelitian ini akan melakukan studi literatur untuk melihat seberapa efektif menerapkan metode scrum pada industri \& organisasi digital, dan dapat mengetahui apakah metode scrum benar-benar mampu diandalkan sebagai skema kerja pengembangan perangkat lunak pada suatu industri maupun organisasi digital.

Kata Kunci: Metode Scrum, Agile methodology, Project Management, SDLC, Industri Digital, Organisasi

\section{PENDAHULUAN}

Perkembangan teknologi informasi dan komunikasi dari waktu ke waktu yang terus meningkat [1] menyebabkan pada era ini perkembangan dan pemanfaatan teknologi sudah mencakup ke segala aspek kehidupan [2] bahkan mencakup organisasi-organisasi industri. Pada era ini sangat banyak pelaku industri digital yang berkembang mulai dari startup, organisasi digital maupun digital agency. Didalam sebuah organisasi atau industri digital pasti akan memerlukan suatu aplikasi maupun sistem informasi. Didalam membuat sebuah sistem informasi maka diperlukanlah suatu metode pengembangan perangkat lunak. Suatu metode yang didalamnya memuat tahapan-tahapan yang diperlukan dalam membangun suatu perangkat lunak atau sistem informasi yang pada zaman ini merupakah hal yang biasa dan semakin berkembangnya teknologi mau tidak mau organisasi dan industri digital harus mengikuti perkembangan tersebut. Maka muncullah berbagai model proses yang menuntun para pengembang sitem informasi maupun perangkat lunak lainnya dalam mengerjakan suatu proyek, diantaranya adalah Software Development Life Cycle (SDLC) Waterfall.

SDCL Waterfall pada prinsipnya mengikuti tahapantahapan yang terorganisir. Tahapan berikutnya tidak akan dimulai ketika tahapan sebelumnya belum diselesaikan dan disetujui karena masing-masing tahapan tersebut saling terikat 
dan memberikan informasi satu dengan lainnya [3]. Metode Waterfall sangat menekankan kepada requirement yang jelas pada suatu perangkat lunak yang akan dikembangkan sebelum tercapai komitmen antara client dengan pihak pengembang. Dan juga metode ini memiliki masalah dimana proses ini membutuhkan usaha dan biaya yang sangat tinggi ketika harus menulis dokumentasi disetiap fase pengembangan. Beberapa masalah yang sering terjadi fitur yang kurang lengkap setelah di check oleh client, permasalah pada ui/ux design perangkat lunak tersebut, hingga perubahan pada suatu fitur yang sudah selesai di develop oleh tim developer. Metode Waterfall ini juga tidak bisa merespon adanya perubahan didalam pengembangan perangkat lunak atau sistem informasi yang akan dikembangkan dan sedikitnya kesempatan client untuk terlibat dalam memberikan umpan balik pada setiap fase pengembangan. Dikarena dalam manajemen proyek menggunakan waterfall setiap tahapan harus diselesaikan terlebih dahulu sebelum beralih ke tahap selanjutnya atau dengan kata lain metode ini menuntut pengembangan perangkat lunak yang terorganisir [4] yang spesifikasi awalnya sudah diketahui dan tidak ada perubahan dalam masa development.

Kemampuan teknologi informasi dalam meningkatkan efisiensi dan efektifitas proses bisnis pada suatu organisasi digital dipercaya mampu menjadi alat bantu dalam mempercepat langkah organisasi digital seperti digital agency, industri digital dan lainnya untuk mencapai tujuan bisnisnya [5]. Tidak hanya itu teknologi informasi juga memberikan dampak positif pada lingkungan kerja dan saling terkaitnya kebutuhan dari manajemen pengembangan perangkat lunak [6], yang mulai berkembang kearah yang lebih professional dan efisien serta bisa lebih flexible dalam penggunaannya [7]. Untuk itu penelitian ini dibuat untuk meningkatkan standar mutu dalam manajemen suatu proyek dan mengurangi masalah yang timbul akibat manajemen proyek yang monoton yang masih menggunakan metode waterfall, maka akan diimplementasi metode baru yaitu metode Scrum. Scrum adalah metodologi manajemen perangkat lunak yang responsive serta berbasis metodologi agile yang mampu memberikan value dan manfaat yang terbaik terhadap suatu peranti lunak yang akan dikembangkan [8].

Metode scrum dalam pelaksanaannya tidak hanya sebagai model untuk pengembangan perangkat lunak akan tetapi lebih kepada manajemen pengembangan perangkat lunak sehingga project manager, scrum master, dan tim yang terlibat dapat secara mudah mengontrol tugas-tugas yang ada supaya kinerja menjadi lebih cepat dan efisien [9]. Metode ini juga banyak digunakan oleh beberapa praktisi teknologi informasi karena dapat mengetahui secara cepat dan tepat resiko dan kualitas perangkat lunak yang dikembangkan [10].

Maka pada penelitian ini dilakukan studi literatur untuk melihat seberapa efektif menerapkan metode scrum pada industri \& organisasi digital, dan dapat mengetahui peranan project management system dalam menghandle metode scrum serta dapat mengetahui apakah metode scrum benar-benar mampu sebagai skema kerja dalam pengembangan perangkat lunak pada suatu industri maupun organisasi digital.

\section{SOFTWARE DEVELOPMENT LIFE CYCLE}

Beberapa kajian pustaka yang digunakan dalam penelitian ini mengacu pada beberapa litetature mengenai pengembangan perangkat lunak. Yang pertama adalah litetature mengenai SDCL. SDLC atau Software Development Life Cycle adalah suatu metodologi yang dipakai untuk merancang, membangun, dan memelihara sistem atau perangkat lunak [11]. Menurut Simarmata, SDLC mengarah pada model dan proses yang digunakan dalam mengembangkan piranti lunak dan menguraikan proses yang terjadi, yaitu pengembang menerima perpindahan dari permasalahan ke solusi [12]. Pada SDCL terdapat banyak model yang sering digunakan yaitu waterfall, RAD, The $V$ Model, Prototype, dan Agile. Dengan perkembangan zaman SDLC atau model pengembangan perangkat lunak semakin berkembang dan dalam beberapa kasus mulai digunakannya model Agile. Metodologi Agile merupakan salah satu dari metodologi yang digunakan untuk pengembangan perangkat lunak. Kata Agile berarti cepat, ringan, bebas, dan waspada [7]. Metodologi agile merupakan metodologi pengembangan perangkat lunak yang mempunyai prinsip yang sama atau sebuah metodologi untuk pengembangan suatu sistem dengan waktu yang pendek dan memerlukan adaptasi yang cepat dari pengembang terhadap perubahan dalam bentuk apapun [13]. Menurut Agile Alliance, ada 12 prinsip dalam penerapan Agile yaitu:

- Kepuasan pelanggan adalah prioritas paling utama dengan menghasilkan produk lebih awal dari yang di targetkan.

- Menerima perubahan kebutuhan, sekalipun diakhir pengembangan.

- Penyerahan hasil dalam hitungan waktu dua minggu sampai dua bulan.

- Bagian bisnis dan pengembang bekerja sama setiap hari selama proyek berlangsung.

- Membangun proyek dilingkungan orang-orang yang bermotivasi untuk dapat menyelesaikan proyek.

- Komunikasi dengan tatap muka langsung adalah komunikasi yang efektif dan efisien.

- Software yang berfungsi dan layak adalah ukuran utama dari kemajuan proyek

- Dukungan yang stabil dari sponsor, pihak pengembang, dan pengguna diperlukan untuk menjaga hubungan baik yang berkesinambungan

- Perhatian kepada teknis dan desain yang bagus meningkatkan sifat kemahiran atau kelincahan suatu perangkat lunak

- Kesederhanaan

- Arsitektur, desain yang efisien dan menarik muncul dari tim yang mengatur dirinya sendiri

- Secara berkala tim mengevaluasi diri dan mencari cara untuk lebih efektif lagi dan segera melakukannya.

Kedua belas prinsip tersebut menjadi suatu dasar bagi modelmodel proses yang mempunyai sifat metodologi agile [14]. Didalam perkembangannya metodologi Agile memiliki beberapa turunan salah satunya adalah metode scrum. Metode atau model scrum merupakan metode turunan dari metodologi Agile. Metode scrum sudah dikembangkan oleh Jeff 
DOI: https://doi.org/10.24843/MITE.2020.v19i02.P12

Sutherland sejak tahun 1993 yang tujuannya adalah menjadikan scrum sebagai metode pengembangan dan manajemen metodologi yang mengikuti prinsip-prinsip metodologi Agile [15]. Metode scrum merupakan metode pengembangan perangkat lunak yang responsive dan berbasis metodologi agile yang mampu memberikan value dan manfaat yang terbaik terhadap suatu perangkat lunak yang akan dikembangkan [8]. Metode scrum lebih berfokus pada manajemen proyek yang dimana keadaannya dalam perencanaan awalnya menyusahkan, komponennya belum begitu jelas sehingga menggunakan feedback berulang dalam mengontrol setiap fase atau prosesnya. Didalam scrum memiliki 3 role utama yaitu: product owner, scrum master, dan development team atau tim pengembang [16]. Yang dimaksud Product Owner (PO) atau pemilik produk, merupakan seorang profesional yang memiliki pengetahuan yang mendalam mengenai produk yang akan dikembangkan. Sementara itu scrum Team atau tim development (Tim Pengembang), yang beranggotakan indvidu-individu yang mampu mengorganisasikan dirinya sendiri dan merupakan sebuah tim multifungsi dalam pengembangan suatu perangkat lunak. Kemudian yang dimaksud scrum Master, adalah orang yang bertanggung jawab untuk mengarahkan tim scrum (scrum team) bekerja menuju arah dan tujuan yang benar dan mengatasi semua rintangan dan halangan yang dapat mempengaruhi kinerja mereka dalam membuat suatu perangkat lunak [17].

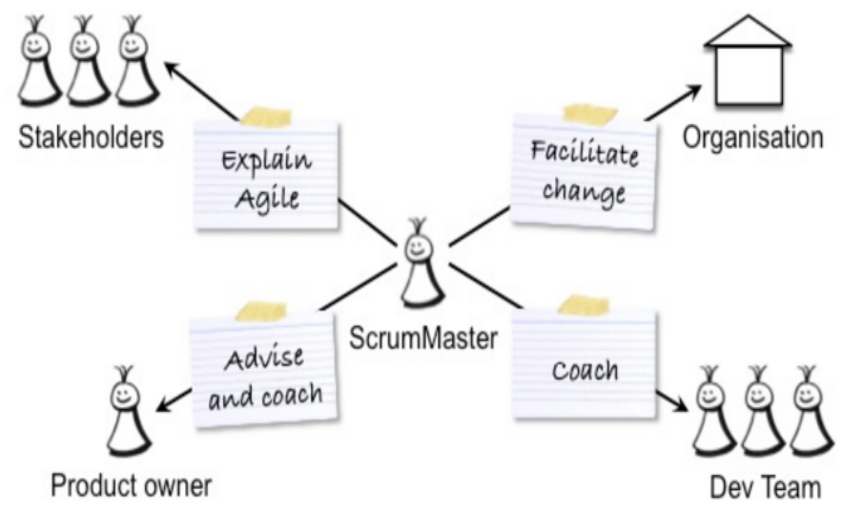

Gambar 1: Role pada metode scrum

Ketiga tahapan ini bekerja dalam proses pengembangan yang terus-menerus didalam sebuah iterasi yang disebut Sprint. Metode scrum memiliki beberapa langkah dalam pelaksanaannya yaitu [18]:

1.Pengimplementasian Product Backlog yang berisi daftar tasks yang harus dikerjakan dalam proyek tersebut, perkiraan waktu yang dibutuhkan, dan jumlah tim yang terlibat.

2.Pengimplementasian perhitungan rencana Design Sprint.

3.Hasil perhitungan dari Design Sprint.

4.Analisis proses metode scrum dalam bentuk Burndown Chart.

Kemudian pada aktifitasnya scrum memiliki pendekatan yang hampir sama dengan langkah-langkah dalam pelaksanaan scrum. Pendekatan scrum memiliki terdiri dari aktifitas, yaitu [19]:

1. Backlog
Backlog adalah list dari fitur - fitur atau kebutuhan yang diinginkan oleh client. Pada backlog ini bisa bertambah atau berkurang.

2. Sprints

Sprints merupakan iterasi atau fase kerja yang diperlukan untuk menyelesaikan list pada backlog sesuai dengan waktu yang ada pada time-box.

3. Scrum Meetings

Aktifitas scrum meetings merupakan meeting rutin atau pertemuan yang rutin dilakukan setiap hari pada pagi hari untuk mengevaluasi apa yang sedang dikerjakan, kendala yang ada, dan target penyelesaian task selanjutnya.

4. Demo

Memberikan peningkatan perangkat lunak kepada klien yang telah diimplementasikan dapat ditunjukan dan dievaluasi oleh klien.

Didalam sebuah model pengembangan perangkat lunak tentunya perlu suatu sistem informasi manajemen untuk mengatur semua proses tersebut tidak terkecuali metode scrum, maka muncullah suatu sistem informasi manajemen proyek atau Project Management System.Project Management System adalah suatu sistem informasi manajemen yang berfokus pada pengendalian atau memanajemen suatu project perangkat lunak yang akan di kembangkan. Sistem manajemen proyek merupakan cara memanajemen suatu proyek perangkat lunak dengan merencanakan, mengatur, dan mengelola seluruh aspek yang di perlukan [20]. Pada sistem manajemen proyek terdapat beberapa aspek yaitu: Estimasi kegiatan, penjadwalan, manajemen anggaran pembuatan perangkat lunak, alokasi sumber daya manusia, manajemen mutu atau kualitas suatu perangkat lunak yang dikembangkan, manajemen resiko, manajemen dalam mengambil suatu keputusan untuk kedepannya [20]. Didalam perkembangannya project management system memiliki software tersendiri yang bisa dipakai untuk memanajemen suatu proyek. Software software ini ada yang free ada juga yang berbayar, diantaranya: Microsoft Project, Trello, Basecamp, Oracle Primavera, Smartsheet, Asana, Teamwork, dan Jira [21].

\section{METODE PENELITIAN}

Pada penelitian ini, peneliti memulai langkah-langkah dalam pengumpulan data dengan persiapan penelitan menggunakan research design, memaksimalkan study literature untuk pemahaman yang mendalam mengenai metode scrum dalam pengimplementasiannya didalam manajemen suatu proyek, selain study literature penulis juga melakukan teknik pengumpulan data lainnya yang dipakai dalam studi kasus penelitian ini. Teknik yang digunakan pada penelitian ini yaitu Teknik observasi dan observasi yang dilakukan adalah jenis observasi "nonparticipant observation". Dimana peneliti tidak terlibat langsung dalam pengimplementasian metode scrum tersebut. Dalam penelitian ini peneliti manerapkan metode Literature Review yang dimana sangat berguna untuk melakukan ulasan penelitian dengan melakukan penggolongan dan perbandingan terhadap beberapa penelitian yang telah ada baik berupa artikel, jurnal, paper atau conference.

Hisyam Rahmawan Suharno: Analisis Penerapan Metode Scrum....

p-ISSN:1693 - 2951; e-ISSN: 2503-2372 


\section{IV.HASIL DAN PEMBAHASAN}

Pada penelitian ini, dilakukan literature review dari jurnal yang terkait implementasi metode scrum pada industri dan organisasi digital. Pada bagian ini akan dilakukan perbandingan dari 7 jurnal yang meneliti mengenai metode pembangunan perangkat lunak dengan menggunakan scrum pada industri dan organisasi digital, dari beberapa jurnal tersebut penulis mendefinisikan menjadi 7 pertanyaan, dalam table perbandingan baris tabel sebagai judul jurnal yang ditinjau dan kolom sebagai kriteria-kriteria hasil tinjauan [22]. 7 pertanyaan tersebut direprentasikan oleh pertanyaan "Research Question (RQ)" yang penulis telah rangkum seperti berikut:

RQ 1: Apakah efektif menerapkan scrum framework pada industri \& organisasi digital?

RQ 2: Apakah kualitas perangkat lunak semakin baik saat diterapkan metode scrum?

RQ 3: Apakah fungsionalitas diutamakan dalam penerapan Scrum framework pada industri \& organisasi digital?

RQ4: Apakah didalam penerapan metode scrum telah memanfaatkan project management system?

RQ 5: Apakah diperlukan banyak team dalam menerapkan scrum framework pada industri \& organisasi digital?
RQ 6: Apakah diperlukan pengujian perangkat lunak saat menerapkan scrum framework pada industri \& organisasi digital?

RQ 7: Apakah kebutuhan awal harus terpenuhi ketika menerapkan metode scrum?

Untuk membatasi ruang lingkup literature review maka dibutuhkan filter kata kunci dengan menggunakan filter berdasarkan kriteria berikut:

1. Fokus pada analisa metode scrum dan pengimplementasiannya pada industri dan organisasi digital.

2. Sumber dalam bahasa Inggris maupun Bahasa Indonesia dan memberikan jawaban atas pertanyaan penelitian dan kata kunci penelitian.

3. Publikasi literatur review dalam bentuk jurnal, paper, makalah atau conference mulai tahun 2015 hingga 2019

Setelah adanya pembatasan pada ruang lingkup literature review dan setelah ditentukannya kriteria dan Researh Question, maka dari beberapa jurnal yang ada dipilihlah 7 jurnal yang meneliti mengenai metode pembangunan perangkat lunak dengan menggunakan scrum yang relevan untuk selanjutnya dikaji lebih lanjut dan dijadikan pembahasan penelitian. Pembahasan jurnal yang digunakan pada tinjauan literatur ini ditunjukkan pada Tabel I

TABEL I

LITERATURE REVIEW MENGENAI SCRUM

\begin{tabular}{|c|c|c|c|c|}
\hline Judul & Penulis & Tahun & Fitur & Kesimpulan \\
\hline $\begin{array}{l}\text { Scrum Method } \\
\text { Implementation in A } \\
\text { Software Development } \\
\text { Project Management [7]. }\end{array}$ & $\begin{array}{l}\text { Putu Adi Guna } \\
\text { Permana }\end{array}$ & 2015 & $\begin{array}{ll}\text { - } & \text { Partial Prepayment Feature } \\
\text { - } & \text { Top Up \& Renewal Feature } \\
\text { - } & \text { Early Termination Feature }\end{array}$ & $\begin{array}{l}\text { Scrum adalah bagian dari metode Agile yang } \\
\text { mengutamakan kecepatan dan fleksibilitas dalam } \\
\text { proyek pengembangan perangkat lunak. Dalam } \\
\text { pengimplementasian scrum kualitas dan project risk } \\
\text { akan cepat terlihat. Kecepatan pengembangan akan } \\
\text { jauh lebih cepat dan efisien. Feedback dari customer } \\
\text { langsung bisa terlihat. Serta aplikasi live bisa } \\
\text { terlihat hasilnya per product backlog. }\end{array}$ \\
\hline $\begin{array}{l}\text { Perancangan Dashboard } \\
\text { Sistem Informasi Untuk } \\
\text { Agile Manajemen Proyek } \\
\text { Dengan Menggunakan JIRA } \\
\text { - Studi Kasus Di PT. } \\
\text { FlasHiz Indonesia [23]. }\end{array}$ & $\begin{array}{l}\text { Prawido Utomo, } \\
\text { Setiawan, Franky } \\
\text { Wibisono Prayitno }\end{array}$ & 2015 & $\begin{array}{ll}\text { - } & \text { Fitur Manajemen Developer } \\
\text { - } & \text { Fitur Manajemen Quality } \\
& \text { Assurance } \\
\text { - } & \text { Fitur list issues dari semua } \\
& \text { proyek } \\
\text { - } & \text { Fitur Activity Development } \\
& \text { (ToDo, onProgress,Testing) }\end{array}$ & $\begin{array}{l}\text { Penggunaan sistem informasi manajemen proyek } \\
\text { pada suatu company merupakan suatu keharusan } \\
\text { karena bisa mengawasi dan mengendalikan setiap } \\
\text { proyek yang ada walau menggunakan metode kerja } \\
\text { scrum(agile), salah satu sistem informasi } \\
\text { manajemen yang mensupport metode itu adalah } \\
\text { JIRA. Sistem ini digunakan lebih dari manajemen } \\
\text { proyek, tergantung kebutuhan dari perusahaan itu } \\
\text { sendiri. }\end{array}$ \\
\hline $\begin{array}{l}\text { Implementasi Metodologi } \\
\text { Scrum Dalam } \\
\text { Pengembangan Sistem } \\
\text { Pembayaran Elektronik Pada } \\
\text { Usaha Mikro Kecil } \\
\text { Menengah [24]. }\end{array}$ & $\begin{array}{l}\text { Taufiq Rizaldi, Dwi } \\
\text { Putro Sarwo S, Hendra } \\
\text { Yufit R. }\end{array}$ & 2016 & $\begin{array}{ll} & \text { Fitur login user } \\
\text { - } & \text { Fitur manajemen menu yang } \\
& \text { dijual } \\
\text { - } & \text { Fitur kalkulator untuk kasir } \\
\text { - } & \text { Fitur cetak laporan } \\
\text { - } & \text { Fitur Manajemen } \text { user }\end{array}$ & $\begin{array}{l}\text { Implementasi Metodologi scrum Dalam } \\
\text { Pengembangan Sistem Pembayaran Elektronik Pada } \\
\text { Usaha Mikro Kecil Menengah dalam skala kecil dan } \\
\text { dengan tim yang kecil sangat tepat digunakan } \\
\text { karena dapat mengantisipasi perubahan yang } \\
\text { mungkin bisa terjadi didalam proses development } \\
\text { sistem dan sesuai dengan kebutuhan UMKM } \\
\text { dengan mengutamakan fungsionalitasnya. }\end{array}$ \\
\hline
\end{tabular}

\begin{tabular}{|c|c|c|c|c|}
\hline Judul & Penulis & Tahun & Fitur & Kesimpulan \\
\hline $\begin{array}{l}\text { Implementasi Framework } \\
\text { Scrum Dalam } \\
\text { Pengembangan Sistem } \\
\text { Informasi Jabatan } \\
\text { Fungsional Akademik [18]. }\end{array}$ & $\begin{array}{l}\text { Harjono, Muhammad } \\
\text { Hamka }\end{array}$ & 2017 & $\begin{array}{ll}\text { - } & \text { Validasi riwayat usulan dan } \\
& \text { data JAFA } \\
\text { - } & \text { Penyimpanan data usulan } \\
& \text { baru } \\
\text { - } & \text { Pemrosesan data usulan }\end{array}$ & $\begin{array}{l}\text { Pada pengembangan sistem informasi JAFA } \\
\text { terdapat } 10 \text { Task dan dibagi menjadi } 3 \text { sprint. Sprint } \\
\text { pertama (2 Task) dengan estimasi } 16 \text { hari kerja. } \\
\text { Sprint kedua ( } 5 \text { Task) dengan estimasi } 40 \text { hari kerja. } \\
\text { Sprint ketiga ( } 3 \text { Task) dengan estimasi } 20 \text { hari kerja. }\end{array}$ \\
\hline
\end{tabular}




\begin{tabular}{|c|c|c|c|c|}
\hline & & & 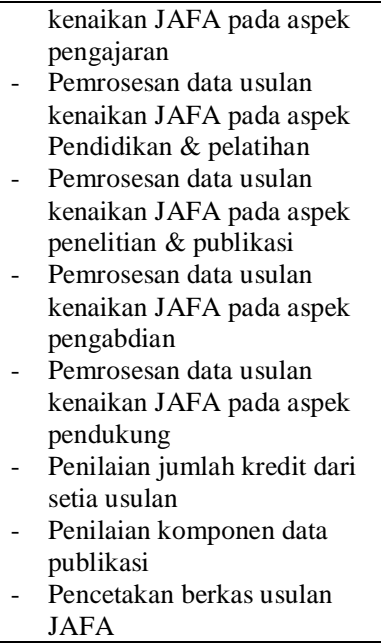 & $\begin{array}{l}\text { Sehingga dapat disimpulkan dari implementasi } \\
\text { ketiga sprint tersebut maka metode scrum } \\
\text { merupakan metode yang tepat untuk meningkatkan } \\
\text { kecepatan waktu dalam pengembangan perangkat } \\
\text { lunak ditunjukkan dengan garis actual tasks } \\
\text { remaining selalu berada di bawah garis ideal task } \\
\text { remaining dengan rata-rata focus factor developer } \\
\text { adalah } 0.6 \text {. }\end{array}$ \\
\hline $\begin{array}{l}\text { Implementasi Kerangka } \\
\text { Kerja Scrum Pada } \\
\text { Manajemen Pengembangan } \\
\text { Sistem Informasi [25]. }\end{array}$ & M. Arif Firdaus & 2017 & $\begin{array}{l}\text { - } \quad \text { Login Feature } \\
\text { - } \quad \text { Login Feature } \\
\text { - } \text { Customer Page } \\
\text { - } \text { Main Page } \\
\text { - } \quad \text { Admin Page } \\
\text { - } \quad \text { About Us Page }\end{array}$ & $\begin{array}{l}\text { Scrum lebih mengutamakan fungsionalitas, karena } \\
\text { didalam fungsionalitas scrum terdapat kualitas, } \\
\text { testing, dokumentasi, review dan lainnya. }\end{array}$ \\
\hline $\begin{array}{l}\text { Implementasi Scrum Model } \\
\text { Development Pada Rezvac } \\
\text { Cloud Reservation Dan } \\
\text { Payment System [26]. }\end{array}$ & $\begin{array}{l}\text { I Gede Totok } \\
\text { Suryawan, Ary Wira } \\
\text { Andika }\end{array}$ & 2018 & $\begin{array}{ll}\text { - } & \text { Fitur Pengelolaan data client } \\
\text { - } & \text { Fitur integrasi website } \\
\text { dengan sistem Rezvac Cloud } \\
\text { Reservation } \\
\text { - } & \text { Fitur menajemen } \text { customer } \\
& \text { tour } \\
\text { - } & \text { Fitur manajemen } \text { transport } \\
\text { - } & \text { Fitur manajemen } \text { tour } \\
\text { - } & \text { Fitur booking system }\end{array}$ & $\begin{array}{l}\text { Metode scrum bisa di implementasikan pada } \\
\text { pengembangan sistem Rezvac Cloud Reservation } \\
\text { Dan Payment System dengan baik dan memakan } \\
\text { waktu yang relative cepat. Feedback } \\
\text { dari client dapat terkoordinasi dengan baik, } \\
\text { sehingga risiko pengembangan sistem bisa terlihat } \\
\text { lebih cepat. mengurangi terjadinya software crisis }\end{array}$ \\
\hline $\begin{array}{l}\text { Aplikasi Monitoring } \\
\text { Perkembangan Janin } \\
\text { (Antenatal Care) Dengan } \\
\text { Metode Scrum Berbasis } \\
\text { Perangkat Mobile [27]. }\end{array}$ & $\begin{array}{l}\text { Zaki Imaduddin, } \\
\text { Henry Saptono, Syifa } \\
\text { Tazkiy Fauziah, Hilmy } \\
\text { Abidzar Tawakal, } \\
\text { Dede Hamzah }\end{array}$ & 2015 & $\begin{array}{ll}\text { - } & \text { Fitur Login \& Register } \\
\text { - } & \text { Fitur Manajemen Pasien } \\
\text { - } & \text { Fitur Pencatatan Riwayat } \\
& \text { Kehamilan Pasien } \\
\text { - } & \text { Fitur Melihat Grafik } \\
& \text { Perkembangan janin pasien } \\
\text { - } & \text { Fitur menghitung taksiran } \\
& \text { kelahiran } \\
\text { - } & \text { Fitur Notification } \\
\text { - } & \text { Fitur Search pasien } \\
\end{array}$ & $\begin{array}{l}\text { Scrum sendiri digunakan untuk mengelola } \\
\text { pengembangan perangkat lunak yang tidak terlalu } \\
\text { kompleks, maka daripada itu digunakanlah metode } \\
\text { scrum dalam membantun aplikasi ini. Selain } \\
\text { menggunakan pendekatan scrum aplikasi ini juga } \\
\text { menggunakan hybrid application development. } \\
\text { Aplikasi ini sangat membantu bidan dalam mencatat } \\
\text { dan memantau pertumbuhan janin dari pasien. }\end{array}$ \\
\hline
\end{tabular}

Setelah melakukan kajian literature review terhadap 7 mendefinisikan menjadi 7 kriteria yang akan menjadi jurnal yang berkaitan dengan pengembangan perangkat lunak parameter perbandingan. Di dalam tabel perbandingan baris menggunakan metode scrum pada industri maupun organisasi tabel sebagai judul jurnal yang ditinjau dan kolom sebagai digital, maka dari beberapa jurnal tersebut penulis kriteria-kriteria hasil tinjauan.

TABEL II

PERBANDINGAN PENELITIAN DALAM JURNAL

\begin{tabular}{|c|c|c|c|c|c|c|c|}
\hline Judul & $\begin{array}{c}\text { Keefektifan } \\
\text { Waktu }\end{array}$ & $\begin{array}{c}\text { Faktor } \\
\text { Kualitas }\end{array}$ & $\begin{array}{c}\text { Fungsio- } \\
\text { nalitas }\end{array}$ & $\begin{array}{l}\text { Pemanfaatan } \\
\text { Project } \\
\text { Management } \\
\text { System } \\
\end{array}$ & $\begin{array}{c}\text { Diperlukan } \\
\text { Banyak } \\
\text { Anggota } \\
\text { Team } \\
\end{array}$ & $\begin{array}{l}\text { Pengujian } \\
\text { Perangkat } \\
\text { Lunak }\end{array}$ & $\begin{array}{c}\text { Kebutuhan } \\
\text { Awal } \\
\text { Harus } \\
\text { Terpenuhi } \\
\end{array}$ \\
\hline $\begin{array}{l}\text { Scrum Method Implementation in A Software } \\
\text { Development Project Management [7]. }\end{array}$ & $\checkmark$ & $\checkmark$ & $\checkmark$ & X & $X$ & $\checkmark$ & X \\
\hline $\begin{array}{l}\text { Perancangan Dashboard Sistem Informasi Untuk } \\
\text { Agile Manajemen Proyek Dengan Menggunakan } \\
\text { JIRA - Studi Kasus Di PT. FlasHiz Indonesia [23]. }\end{array}$ & $\checkmark$ & $X$ & $\checkmark$ & $\checkmark$ & X & $X$ & X \\
\hline Judul & $\begin{array}{c}\text { Keefektifan } \\
\text { Waktu }\end{array}$ & $\begin{array}{l}\text { Faktor } \\
\text { Kualitas }\end{array}$ & $\begin{array}{l}\text { Fungsio- } \\
\text { nalitas }\end{array}$ & $\begin{array}{l}\text { Pemanfaatan } \\
\text { Project } \\
\text { Management } \\
\text { System } \\
\end{array}$ & $\begin{array}{c}\text { Diperlukan } \\
\text { Banyak } \\
\text { Anggota } \\
\text { Team } \\
\end{array}$ & $\begin{array}{l}\text { Pengujian } \\
\text { Perangkat } \\
\text { Lunak }\end{array}$ & $\begin{array}{l}\text { Kebutuhan } \\
\text { Awal } \\
\text { Harus } \\
\text { Terpenuhi }\end{array}$ \\
\hline
\end{tabular}

Hisyam Rahmawan Suharno: Analisis Penerapan Metode Scrum.... 


\begin{tabular}{|c|c|c|c|c|c|c|c|}
\hline $\begin{array}{l}\text { Implementasi Metodologi Scrum Dalam } \\
\text { Pengembangan Sistem Pembayaran Elektronik Pada } \\
\text { Usaha Mikro Kecil Menengah [24]. }\end{array}$ & $\checkmark$ & $X$ & $\checkmark$ & $X$ & $\mathrm{X}$ & $\checkmark$ & $\checkmark$ \\
\hline $\begin{array}{l}\text { Implementasi Framework Scrum Dalam } \\
\text { Pengembangan Sistem Informasi Jabatan Fungsional } \\
\text { Akademik [18]. }\end{array}$ & $\checkmark$ & $\checkmark$ & $\checkmark$ & $X$ & $X$ & $X$ & $\checkmark$ \\
\hline $\begin{array}{l}\text { Implementasi Kerangka Kerja Scrum Pada } \\
\text { Manajemen Pengembangan Sistem Informasi [25]. }\end{array}$ & $\checkmark$ & $X$ & $\checkmark$ & $\checkmark$ & $X$ & $X$ & $X$ \\
\hline $\begin{array}{l}\text { Implementasi Scrum Model Development Pada } \\
\text { Rezvac Cloud Reservation Dan Payment System [26]. }\end{array}$ & $\checkmark$ & $\checkmark$ & $\checkmark$ & $X$ & $X$ & $\checkmark$ & $X$ \\
\hline $\begin{array}{l}\text { Aplikasi Monitoring Perkembangan Janin (Antenatal } \\
\text { Care) Dengan Metode Scrum Berbasis Perangkat } \\
\text { Mobile [27]. }\end{array}$ & $\checkmark$ & $X$ & $\checkmark$ & $X$ & $X$ & $\checkmark$ & $X$ \\
\hline
\end{tabular}

Dari perbandingan beberapa literature review jurnal yang sudah didapatkan maka dapat dilihat perbandingan dari ke-7 Research Question yang sudah didefinisikan. Dilihat dari kriteria keefektifan waktu dalam 7 literature review menunjukkan metode scrum sangat efektif dipakai atau diimplementasi pada pengembangan perangkat lunak pada suatu industri atau organisasi digital yang cenderung cepat dan tidak banyak terintegrasi atau tidak terlalu kompleks. Dikarenakan metode scrum mengutamakan kecepatan dan fleksibilitas dalam proyek pengembangan perangkat lunak [7]. Kemudian dilihat dari segi kualitas suatu perangkat lunak dalam 7 literature review menunjukkan metode scrum tidak terlalu mementingkan kualitas suatu perangkat lunak, dilihat dari hanya 3 jurnal yang menunjukkan faktor kualitas juga berpengaruh pada metode scrum, sedangkan 4 jurnal lainnya tidak menunjukkan faktor kualitas berpengaruh pada penerapan metode scrum pada suatu industri atau organisasi digital, dikarenakan scrum lebih mengutamakan fungsionalitas, karena didalam fungsionalitas scrum terdapat kualitas, testing, dokumentasi, dan review [25] sehingga kualitas suatu fungsionalitas sudah berada didalam iterasi sprint pada scrum.

Dari segi fungsionalitas, metode scrum secara umum sangat mengutamakan fungsionalitas, dan pernyataan ini didukung oleh literature review yang sudah dilakukan dan ditunjukkan pada ke-7 penelitian tersebut yang menghasilkan kesimpulan bahwa metode scrum selain mengutamakan keefektifan waktu juga mengutamakan fungsionalitas dari perangkat lunak yang akan dikembangkan. Metode scrum sangat tepat digunakan karena dapat mengantisipasi perubahan yang mungkin bisa terjadi didalam proses development perangkat lunak di industri maupun organisasi digital [24].

Dalam perkembangannya metode pengembangan perangkat lunak memerlukan suatu sistem informasi manajemen proyek untuk menunjang langkah-langkah dari suatu metode tersebut. Pada beberapa penelitian yang sudah di review hanya beberapa penelitian saja yang memanfaatkan project management system. Dari 7 literature review hanya 2 penelitian saja yang memanfaatkan project management system dalam pengembangan perangkat lunaknya di industri digital. Beberapa penelitian masih memakai manual board untuk mengatur backlog dan sprint pada metode scrum. Dalam segi pengembangan perangkat lunak, tim merupakan suatu yang sangat penting karena jika tidak ada tim maka pengembangan perangkat lunak tidak akan berjalan. Akan tetapi tidak semua metode mengharuskan mempunyai banyak anngota dalam suatu tim agar metode tersebut berjalan. Salah satunya metode scrum yang bisa berjalan walau dengan anggota yang sedikit didalam tim. Pernyataan ini juga didukung dengan melihat perbandingan dari beberapa literature review yang sudah dilakukan, menunjukkan beberapa penelitan tidak terlalu memerlukan banyak anggota dalam suatu tim untuk pengembangan perangakat lunak disuatu industri digital menggunakan metode scrum. Pada penelitian yang yang berjudul "Scrum Method Implementation in A Software Development Project Management" [7] dalam penelitian tersebut hanya beranggotakan 6 orang saja untuk menjalankan role dari metode scrum tersebut. Metode scrum memungkinkan dengan tim yang kecil sangat tepat digunakan karena dapat mengantisipasi perubahan yang mungkin bisa terjadi didalam proses development suatu perangat lunak [24]. Karena metode scrum sendiri digunakan untuk mengelola pengembangan perangkat lunak yang tidak terlalu kompleks [27] yang tidak terlalu membutuhkan tim yang besar.

Didalam pengambangan perangkat lunak dengan metode apapun tentu ada pengujian yang dilakukan apakah perangkat lunak yang dikembangkan sesuai dengan kebutuhan. Begitu pula dengan metode scrum dalam pengimplementasiannya tetap ada pengujian yang membedakan hanyalah pada metode scrum yang di uji adalah masing-masing sprint pada suatu backlog atau yang diuji pada scrum adalah fungsionalitasnya dari masing-masing sprint. Bukan pengujian diakhir seperti beberapa metode lainnya. Dalam Tabel 2 didapatkan 4 dari 7 penelitan menggunakan pengujian perangkat lunak berupa pengujian blackbox maupun whitebox. Selain itu juga pengujian bisa berupa feedback dari client. Feedback dari client dapat terkoordinasi dengan baik, sehingga risiko pengembangan sistem bisa terlihat lebih cepat. mengurangi terjadinya software crisis [26]. Pengembangan perangkat lunak tidak lepas dari kebutuhan awal yang dapat menginisialisasi suatu project. Di dalam beberapa metode pengembangan perangkat lunak kebutuhan awal dari beberapa metode tersebut berbeda-beda. Didalam metode scrum tidak terlalu membutuhkan kebutuhan awal yang sangat jelas, bisa saja beberapa kebutuhan awal yang sudah fix atau sudah umum, maka dari itu didalam literature review yang sudah dilakukan, beberapa penelitian diketahui tidak terlalu menjelaskan kebutuhan awal yang jelas, dikarenakan metode scrum sendiri digunakan untuk mengelola pengembangan perangkat lunak yang tidak terlalu kompleks, dan kebutuhannya belum begitu jelas [27] dan dapat 
mengantisipasi perubahan yang mungkin bisa terjadi didalam proses development.

\section{KESIMPULAN}

Berdasarkan analisis yang sudah dibuat menggunakan perbandingan literature review dari beberapa jurnal, didapatkan bahwa metode scrum didalam beberapa kriteria memang lebih unggul daripada metode pengembangan perangkat lunak lainnya dikarenakan metode scrum sangat efektif diimplementasi pada pengembangan perangkat lunak pada suatu industri atau organisasi digital yang relatif cepat, tidak memakan banyak waktu, dan tidak banyak terintegrasi atau tidak terlalu kompleks.

Metode scrum pada dasarnya mengutamakan kecepatan dan fleksibilitas dalam proyek pengembangan perangkat lunak, selain itu metode scrum juga mengutamakan fungsionalitas yang didalamnya sudah terdapat hasil dari pengujian fungsionalitas yang mengakibatkan kualitas perangkat lunak dari segi fungsionalitas sudah terjamin. Anggota dalam tim pun tidak terlalu banyak, akan tetapi tetap mengikuti role yang sudah ada pada metode scrum dan client menjadi lebih bisa aktif memberikan feedback atau umpan balik mengenai fungsionalitas dari perangkat lunak yang akan dikembangkan. Akan tetapi tidak semua pengembangan perangkat lunak cocok menggunakan scrum dikarenakan dalam metode scrum haruslah orang yang ahli atau seorang scrum master dan untuk menjadi seorang scrum master harus mampu menguasai bagian teknikal dan analisis. Maka sebelum menggunakan metode scrum, sebaiknya disesuaikan terlebih dahulu untuk kebutuhan, ruang lingkup pengerjaan, dan waktu pengembangan perangkat lunak tersebut.

\section{REFERENSI}

[1] M. R. Suarimbawa, Linawati and N. P. Sastra, "AnalisisPemanfaatan Internet di Pusat Pemerintahan Kabupaten Badung," Majalah Ilmiah Teknologi Elektro, vol. XVII, no. 2, pp. 185-190, 2018.

[2] A. Saputra, M. Sudarma and D. M. Wiharta, "Sistem Pelaporan Parkir Liar Berbasis Geolocationdi Kota Denpasar," Majalah Ilmiah Teknologi Elektro, vol. XVIII, no. 1, pp. 127-132, 2019.

[3] I. Binanto, "Analisa metode classic life cycle (Waterfall) untuk pengembangan perangkat lunak multimedia," in Seminar Nasional Sains dan Teknologi Informasi (SeNASTI), Makassar, 2014.

[4] M. Solekhah, N. J. L. Marfu'ah, L. V. Fauzia, V. N. Anisah, N. A Ningsih, S. Musdalifah and Z. Zukhri, "Implementasi Metode Waterfall dalam Pengembangan Aplikasi Manajemen Administrasi Surat untuk Divisi Administrasi Umum dan Humas Fakultas Teknologi Industri," in Seminar Nasional Aplikasi Teknologi Informasi (SNATi), Yogyakarta, 2017.

[5] I. K. N. Adi Jaya, I. M. O. Widyantara and R. S. Hartati, "Audit Manajemen Sumber Daya Dan Pengkuruan Performa Sistem Informasi Akademik Universitas Hindu Indonesia Menggunakan Framework COBIT 4.1," Majalah Ilmiah Teknologi Elektro, vol. XVIII, no. 1, pp. 35-40, 2019.

[6] P. Rola and D. Kuchta, "Implementing Scrum Method in International Teams - A Case Study," Open Journal of Social Sciences, vol. III, no. 7, pp. 300-305, 2015.

[7] P. A. G. Permana, "Scrum Method Implementation in a Software

Hisyam Rahmawan Suharno: Analisis Penerapan Metode Scrum....
Development Project Management," (IJACSA) International Journal of Advanced Computer Science and Applications, vol. VI, no. 9, pp. 198204, 2015.

[8] R. Kurnia, "Pemantauan Kinerja Developer Pada Kerangka Kerja Scrum Melalui Dasbor Berbasis Business Intelligence," Electronic Theses \& Dissertations Gadjah Mada University, Yogyakarta, 2018.

[9] W. Suharso, B. I. Wicaksono and G. I. Marthasari, "Penerapan Scrum dan Algoritma COCOMO Pada Aplikasi Manajemen Proyek Perangkat Lunak," Journal Sains dan Teknologi Informasi - SATIN, vol. IV, no. 1, pp. 97-104, 2018.

[10] L. Mutawali, B. K. Fathoni and H. Asyari, "Implementasi Scrum Dalam Pengembangan Sistem Informasi Jasa Desain Grafis," Jurnal Manajemen informatika \& Sistem Informasi, vol. III, no. 2, pp. 116-122, 2020.

[11] Nurasiah, "Perencanaan Pengembangan Sistem Informasi Pembayaran Uang Kuliah Dengan Metode SDLC Waterfall," Jurnal Teknologi dan Rekayasa, vol. XIX, no. 3, pp. 72-81, 2014.

[12] A. A. Sofyan, P. Puspitorini and M. A. Yulianto, "Aplikasi Media Informasi Sekolah Berbasis SMS Gateway Dengan Metode SDLC (System Development Life Cycle)," Jurnal SISFOTEK Global, vol. VI, no. $2,2016$.

[13] M. A. Muslim and N. A. Retno, "Implementasi Cloud Computing Menggunakan Metode Pengembangan Sistem Agile," Scientific Journal of Informatics, vol. I, no. 1, pp. 29-38, 2014.

[14] K. Beck, M. Beedle and A. v. Bennekum, "agilealliance.org," agilealliance, [Online]. Available: https://www.agilealliance.org/agile101/12-principles-behind-the-agilemanifesto/. [Accessed 13 October 2019].

[15] D. Fernando, Anharudin and Fadli, "Rancang Bangun Aplikasi EPortofolio Hasil Karya Mahasiswa UNSERA Menggunakan Metode Scrum," Jurnal Sistem Informasi, vol. V, no. 1, pp. 7-12, 2018.

[16] S. Ashraf and S. Aftab, "IScrum: An Improved Scrum Process Model," I.J. Modern Education and Computer Science, vol. IX, no. 8, pp. 16-24, 2017.

[17] T. Wijaya, "Penerapan Metode Scrum Dan Virtual Private Network Dalam Perancangan Sistem Ordersales," Creative Communication and Innovative Technology (CCIT Journal), vol. XI, no. 1, pp. 115-125, 2018.

[18] Harjono and M. Hamka, "Implementasi Framework SCRUM dalam Pengembangan Sistem Informasi Jabatan Fungsional Akademik," in Seminar Nasional Hasil Penelitian dan Pengabdian pada Masyarakat, Purwokerto, 2017.

[19] M. A. Firdaus, D. R. Indah and Idris, "Penerapan Scrum Agile Development Dalam Pengembangan Sistem Informasi Monitoring Mahasiswa Bidikmisi Berbasis Web (Studi Kasus Di Universitas Sriwijaya)," in Konferensi Nasional Teknologi Informasi dan Aplikasinya, Palembang, 2016.

[20] L. Hales, “study.com," study.com, [Online]. Available: https://study.com/academy/lesson/project-management-systemdefinition-example.html. [Accessed 13 October 2019].

[21] J. C. Bellah, L. Chen and J. C. Zimmer, "Development Of A Project Management Software Tool : A Design Case," International Journal Of Design For Learning, vol. IX, no. 1, pp. 158-170, 2018.

[22] K. Prihandani, "Tinjauan kualitas pengembangan sistem informasi dengan metode agile," Universitas Singaperbangsa Karawang, Karawang, 2016.

[23] P. Utomo , Setiawan and F. W. Prayitno, "Perancangan Dashboard Sistem Informasi Untuk Agile Manajemen Proyek dengan Menggunakan JIRA -Studi Kasus di PT. FLASHiZIndonesia," Jurnal Sisfotek Global, vol. V, no. 2, pp. 17-24, 2015.

[24] T. Rizaldi, D. P. Sarwo S and H. Y. R, "Implementasi Metodologi SCRUM dalam Pengembangan Sistem Pembayaran Elektronik Pada Usaha Mikro Kecil Menengah," in Seminar Hasil Penelitian dan p-ISSN:1693 - 2951; e-ISSN: 2503-2372 
Pengabdian Masyarakat Dana BOPTN, Jember, 2016.

[25] M. A. Firdaus, "Implementasi Kerangka Kerja Scrum Pada Manajemen Pengembangan Sistem Informasi," in Seminar Nasional Teknologi Informasi dan Multimedia, Yogyakarta, 2017.

[26] I. G. T. Suryawan and A. W. Andika, "Implementasi Scrum Model Development Pada Rezvac Cloud Reservation Dan Payment System," in LP2M - Undhira Bali, Bali, 2018.

[27] Z. Imaduddin, H. Saptono, S. T. Fauziah, H. A. Tawakal and D. Hamzah, "Aplikasi Monitoring Perkembangan Janin (Antenatal Care) Dengan Metode Scrum Berbasis Perangkat Mobile," Jurnal Teknologi Terpadu (JTT), vol. V, no. 1, pp. 34-41, 2019. 